University of Nebraska - Lincoln

DigitalCommons@University of Nebraska - Lincoln

Faculty Papers and Publications in Animal

Science

Animal Science Department

1989

\title{
Anticholesteremic Property of Lactobacillus Acidophilus Yogurt Fed to Mature Boars
}

\author{
A. D. Danielson \\ University of Nebraska-Lincoln \\ E. R. Peo, Jr. \\ University of Nebraska-Lincoln \\ K. M. Shahani \\ University of Nebraska-Lincoln
}

\author{
A. J. Lewis \\ University of Nebraska-Lincoln, alewis2@unl.edu \\ P. J. Whalen \\ University of Nebraska-Lincoln \\ See next page for additional authors
}

Follow this and additional works at: https://digitalcommons.unl.edu/animalscifacpub

Part of the Animal Sciences Commons

Danielson, A. D.; Peo, Jr., E. R.; Shahani, K. M.; Lewis, A. J.; Whalen, P. J.; Amer, M. A.; and Butler, Win, "Anticholesteremic Property of Lactobacillus Acidophilus Yogurt Fed to Mature Boars" (1989). Faculty Papers and Publications in Animal Science. 685.

https://digitalcommons.unl.edu/animalscifacpub/685

This Article is brought to you for free and open access by the Animal Science Department at DigitalCommons@University of Nebraska - Lincoln. It has been accepted for inclusion in Faculty Papers and Publications in Animal Science by an authorized administrator of DigitalCommons@University of Nebraska - Lincoln. 
Authors

A. D. Danielson; E. R. Peo, Jr.; K. M. Shahani; A. J. Lewis; P. J. Whalen; M. A. Amer; and Win Butler 


\title{
ANTICHOLESTEREMIC PROPERTY OF LACTOBACILLUS ACIDOPHILUS YOGURT FED TO MATURE BOARS $1,2,3$
}

\author{
A. D. Danielson ${ }^{4}$, E. R. Peo, Jr. ${ }^{4}$, K. M. Shahani ${ }^{5}$, \\ A. J. Lewis ${ }^{4}$, P. J. Whalen ${ }^{5}$ and M. A. Amer ${ }^{6}$ \\ University of Nebraska ${ }^{4}$ \\ Lincoln 68583-0908
}

\begin{abstract}
Three strains of Lactobacilus acidophilus (LA) were isolated from the feces of mature boars that were not being fed antibiotics from the Nebraska Gene Pool (NGP). All three LA isolates were screened in vitro for anticholesteremic and antimicrobial activities. One strain, LA16, caused the greatest reduction in cholesterol and inhibited both Bacillus subtilis and Escherichia coli the most. LA16 was used to produce 16, 18.9-liter quantities of acidophilus yogurt (AY), over a period of $8 \mathrm{wk}$, for use as a feed ingredient in diets for the NGP boars. Colony forming units (cfu), $\mathrm{pH}$, protein, energy, $\mathrm{Ca}$ and $\mathrm{P}$ were consistent across all 16 batches of yogurt. All of the 18 boars were fed a high-cholesterol diet for a period of $56 \mathrm{~d}$ at a rate of $2.268 \mathrm{~kg} /(\mathrm{hd} \cdot \mathrm{d})$ to furnish $6.661 \mathrm{~g} /(\mathrm{hd} \cdot \mathrm{d})$ of cholesterol. Nine of the boars then were fed $1.81 \mathrm{~kg} /(\mathrm{hd} \cdot \mathrm{d})$ of a second diet that was supplemented with .454 $\mathrm{kg} /(\mathrm{hd} \cdot \mathrm{d})$ of AY. The other nine boars were fed the original diet. Cholesterol intake was the same for the two dietary treatments. Blood samples were collected weekly from the brachial-jugular region and the sera were analyzed for lipids. Acidophilus yogurt reduced serum cholesterol $(P<.01)$ and low density lipoproteins $(P<.08)$, but it had no effect on serum triglycerides $(P>.23)$ or on high density lipoproteins $(P>.11)$.

(Key Words: Lactobacillus acidophilus, Yogurt, Cholesterol, Triglycerides, Lipoproteins, Boar.)
\end{abstract}

J. Anim. Sci. 1989. 67:966-974

\section{Introduction}

Lactobacillus acidophilus (LA) is a gram positive, fastidious organism that has adapted to complex organic substrates. It has been isolated from the intestinal tract of man and animals (Kandler and Weiss, 1986). Metchnikoff (1907) proposed that the longevity of

\footnotetext{
'Published as paper no 8543, Journal Series Nebraska Agric. Res. Div.

${ }^{2}$ The authors thank Henningsen Foods Inc. (Dwight Bergquist) and the Dairy Bureau of Canada for contributing products and partial financial support for this project.

${ }^{3}$ Technical assistance of Sandra Frank, Diana J. Smith and Roy L. Carlson was appreciated.

${ }^{4}$ Dept. of Anim. Sci. Reprint requests should be sent to

E. R. Peo, Jr.

${ }^{5}$ Dept. of Food Sci. and Technol.

'Dept. of Food Sci. and Agric. Chem., McGill Univ., Montreal Quebec, Can.

Received February 1, 1988.

Accepted September 20, 1988.
}

Rumanian and Bulgarian farmers was due to their regular consumption of milk and buttermilk cultured with LA and Lactobacillus bulgaricus. The therapeutic value of LA has since been established for many diseases and disorders of the digestive tract (Shahani and Chandan, 1979; Deeth and Tamime, 1981).

High blood cholesterol, high blood pressure, smoking, obesity and intake of saturated fats have been implicated in heart disease of humans (Pelkonen et al., 1977). Recently, it has been shown that yogurt and other fermented milk products contain some substance(s) that lower serum cholesterol in humans (Mann, 1977), swine (Stahelin et al., 1981), rats (Grunewald, 1982) and rabbits (Thakur and Jha, 1981).

Because the pig is considered to be a good animal model for studies of human atherosclerosis (Pond et al., 1986; Miller and Ullrey, 1987), the objective of our research was to determine the effect of feeding LA yogurt on serum cholesterol, triglycerides and lipopro- 
teins of adult intact male pigs fed diets high in cholesterol.

\section{Experimental Procedure}

Experiment 1. This experiment involved culturing of bacteria isolated from the feces of mature Nebraska Gene Pool (NGP) boars that were not being fed antibiotics. The objective was to find a strain of porcine LA that was capable of assimilating cholesterol (Gilliland et al., 1985) and competing with other organisms within the intestinal tract (Shahani et al., 1976). It generally is accepted that LA is capable of establishment within the gastrointestinal tract (Alm and Pettersson, 1980). By culturing these bacteria from the porcine intestinal tract, the controversy over the adhesion capabilities of LA when transferred from one species of animal to another is eliminated.

Eighteen sexually mature NGP boars were randomly selected. Fecal samples were obtained from the rectum via manual stimulation of the internal and extemal anal sphincters. The feces were collected directly into sterile polyethylene bags and placed on ice. Subsamples of each fecal sample then were diluted with a phosphate buffer (Butterfield's in Leininger, 1976), and plated on acidified Lactobacillus selection (LBS) agar ${ }^{7}$. The plates were incubated at $37^{\circ} \mathrm{C}$ for 36 to $48 \mathrm{~h}$ in a $99 \% \mathrm{CO}_{2}$ environment at $37^{\circ} \mathrm{C}$. After the incubation period, colonies were selected for gram strain. Regular, non-spore forming gram positive rods were the only bacteria that were retained for the determination of species. These were transferred to Lactobacilli MRS broth $^{8}$, where they were grown for $24 \mathrm{~h}$. All strains were tested for the iron-porphyrin enzyme catalase. A sample of each bacteria was placed on a sterile petri plate and a drop of $\mathrm{H}_{2} \mathrm{O}_{2}$ was added. All strains that were positive for catalase were discarded.

Thirty-six Lactobacillus strains were speciated using a procedure developed by $\mathrm{S} . \mathrm{K}$. Frank (personal communication). This proce-

\footnotetext{
${ }^{7}$ BBL Microbiological Systems, Becton Dickinson Co., Cockeysville, MD.

${ }^{8}$ Difco Laboratories, Detroit, MI.

${ }^{9}$ Sigma Chemical Co., St. Louis, MO.

${ }^{10} 15$ th and $\mathrm{U}$, Lincoln, NE.

${ }^{11}$ Central Technical Services, Beckman Instruments Inc., Fullerton, CA.
}

dure employs MRS broth for general propagation, performance of catalase tests, determination of growth temperatures, and obtaining bacterial cell suspensions for use in other tests. Initial separation of the different strains of Lactobacillus was accomplished by fermenting glucose with a Durham insert (Frobisher et al., 1974). Biochemical and physiological tests were performed to differentiate the strains of lactobacilli. After this was completed, additional non-essential confirmation tests were conducted (Rogosa, 1974).

Each strain of LA that was differentiated was screened for bile tolerance, cholesterol reduction and antimicrobial activities. Bile tolerance was determined by growing the different strains in MRS broth supplemented with two levels $\left(.2\right.$ and $.4 \%$ ) of ox gall $^{8}$ (dried, unfractionated bovine bile salts). The organisms were determined to be bile tolerant if appreciable growth occurred after incubation for $24 \mathrm{~h}$ at $37^{\circ} \mathrm{C}$. Cholesterol assimilation was determined by adding a water soluble form of cholesterol (polyoxyethanyl-cholesteryl sebacate $^{9}$ ) to MRS broth at a rate of $10 \mathrm{mg}$ cholesterol/dl. This was done in duplicate at .2 and $.4 \%$ added ox gall to mimic the physiological conditions of the intestinal tract. The bacterial strains were added and incubated in a $99 \% \mathrm{CO}_{2}$ environment for $24 \mathrm{~h}$ at $37^{\circ} \mathrm{C}$. Bacterial cells then were removed by centrifugation and the supernatant fluid was analyzed at the University of Nebraska-Lincoln Health Center Laboratory ${ }^{10}$ for cholesterol ${ }^{11}$.

Antimicrobial activity was tested by a discassay procedure. The medium employed was antibiotic medium $2^{8}$ (Penassay base agar). The agar was placed in sterile petri plates and lawns of both Bacillus subtilis and Escherichia coli were made on separate plates. Sterile discs were inoculated with each strain of LA and placed on each set of plates. The zone of inhibition (lack of microbial growth) was measured after incubation at $37^{\circ} \mathrm{C}$ for 6,12 and $24 \mathrm{~h}$. The 6-h measurement was used to evaluate inhibition because no additional growth appeared after 12 or $24 \mathrm{~h}$.

Each LA strain was used in a preliminary study to produce acidophilus yogurt (AY) (Danielson, 1987). This was done to determine fermentation time, $\mathrm{pH}$ of the final product, degree of whey production, and quality of curd formation. The procedure used to produce the yogurt is outlined in Figure 1. This procedure was scaled down to produce $500 \mathrm{ml}$ of yogurt. 
TABLE 1. ANALYSIS OF PORCINE ACIDOPHILUS YOGURT ${ }^{2}$

\begin{tabular}{lllllll}
\hline \hline Item & $\mathrm{pH}$ & $\begin{array}{l}\text { Plate count } \\
\left(\log \mathrm{CFU} / \mathrm{g}^{\mathrm{d}}\right)\end{array}$ & $\mathrm{GE}^{\mathrm{bc}}, \mathrm{cal} / \mathrm{g}$ & $\mathrm{CP}$, $\%$ & $\mathrm{Ca}^{\mathrm{b}}, \%$ & $\mathrm{~Pb}^{\mathrm{b}}, \%$ \\
\hline Range & $4.47-4.55$ & $7.08-7.77$ & $4,574-4,844$ & $29.3-32.1$ & $.84-.98$ & $.79-.91$ \\
Mean & 4.51 & 7.56 & 4,708 & 30.9 & .91 & .86 \\
\hline
\end{tabular}

analysis of 16, 18.9-liter batches of yogurt.

b $100 \%$ dry matter.

${ }^{\mathrm{G}} \mathrm{GE}=$ gross energy.

${ }^{d} \log$ of colony forming units/g.

Experiment 2. The objective of the research conducted was to determine the effect of feeding AY on serum cholesterol, triglycerides, high density lipoproteins (HDL) and low density lipoproteins (LDL) of mature NGP boars fed a high-cholesterol diet.

The AY was produced at the University of Nebraska Food Processing Center ${ }^{5}$. The nonfat dry milk (NFDM) used to produce AY was of food grade quality. Pasteurization $\left(85^{\circ} \mathrm{C}\right.$ for 30 min) of the milk and NFDM mix was implemented to destroy the thermoduric bacteria normally present in milk. Denaturation of the whey proteins is necessary to obtain a firm curd (Chandan, 1982). The inoculation rate was 2\% LA and 2\% Streptococcus thermophilus for the first five batches of yogurt processed (16 total batches processed), whereas the inoculation rate was 4\% LA and $2 \%$ Streptococcus thermophilus for the remaining 11 batches, $S$. thermophilus was added to the yogurt for a symbiotic effect and to provide a shorter coagulation time. $S$. thermophilus was maintained in reconstituted NFDM (10\% solids) at $43^{\circ} \mathrm{C}$; LA was maintained in the same medium with the addition of yeast extract $^{8}$ at $37^{\circ} \mathrm{C}$. Only 20 - to 24 -h-old vigorously growing bacteria cells were used to inoculate the milk base.

Sixteen 18.9-liter batches of yogurt were produced, and $\mathrm{pH}$, plate count, gross energy, crude protein, $\mathrm{Ca}$ and $\mathrm{P}$ were determined to assess consistency among batches (Table 1). The $\mathrm{pH}$ was measured by a standard $\mathrm{pH}$ meter; the probe was placed directly into the yogurt. The $\mathrm{pH}$ was checked every hour. Plate count was determined by plating a sample of yogurt on acidified LBS agar. These plates were

\footnotetext{
${ }^{12}$ Procedure described in Manual No. 153, Parr Instrument $\mathrm{Co}$., Moline, IL.
}

counted after $24 \mathrm{~h}$ of incubation in a $\mathrm{CO}_{2}$ atmosphere at $37^{\circ} \mathrm{C}$. Yogurt samples were freeze-dried prior to analysis for gross energy, crude protein, $\mathrm{Ca}$ and $\mathrm{P}$. Gross energy was determined using an adiabatic calorimeter ${ }^{12}$. Crude protein was determined by the Kjeldahl method (AOAC, 1984). A method described by AOAC (1984) was used to determine $\mathrm{Ca}$; phosphorus was determined by the molybdenum blue method (Fiske and Subbarow, 1925).

Eighteen NGP boars $(177 \mathrm{~kg}, 18 \mathrm{mo}$.) were used in this phase. The boars were tethered in individual stalls $(.7 \times 2.3 \mathrm{~m})$ and given access to automatic waterers. A pre-test diet high in cholesterol (HC) (Table 2) was fed to all animals for $56 \mathrm{~d}$ prior to the initiation of the experiment. This diet was fed at the rate of

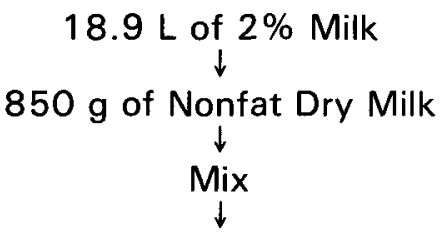

Heat to $85 \mathrm{C}$ and Hold for 30 Minutes $\downarrow$ Cool to $37 \mathrm{C}$ $\downarrow$

Inoculate With $4 \%$ L. acidophilus and $2 \%$ S. thermophilus<smiles>C[Si](C)(C)[Si]</smiles>

Incubate in a Water-Bath at $37 \mathrm{C}$ for 6-8 Hours or Until a Final pH of 4.5 is Attained

$\downarrow$

Refrigerate Immediately

Figure 1. Flow chart for the production of porcine acidophilus yogurt. 
$1.134 \mathrm{~kg} /$ animal every $12 \mathrm{~h}$. The diet contained dried egg yolk, which was added to provide $6.61 \mathrm{~g} /($ animal $\cdot \mathrm{d})$ of cholesterol $(3.305 \mathrm{~g} /$ cholesterol per animal per feeding). Blood samples were obtained at the end of the 56-d pre-test period.

Immediately after the pre-test period, nine of the boars were removed from the $\mathrm{HC}$ diet and fed the yogurt diet shown in Table 2. This diet was fed at the rate of $.907 \mathrm{~kg} /$ animal every $12 \mathrm{~h}$ plus an additional supplementation of $.227 \mathrm{~kg}$ /animal AY (as fed). The yogurt was blended into the diet with a small mixer for 5 min prior to feeding. The other nine boars remained on the $\mathrm{HC}$ diet $(1.134 \mathrm{~kg} /$ animal every $12 \mathrm{~h}$ ). The two respective diets were formulated to contain equal amounts of cholesterol, energy, $\mathrm{Ca}, \mathrm{P}$ and crude protein, but not dry matter. Dry matter was not equalized because humans consuming yogurt would simply substitute yogurt for other feedstuffs. The experimental period was an additional 56 d.

After a 12-h fast, blood samples were obtained from the brachial-jugular region on $\mathrm{d}$ $0,7,14,21,28,35,42,49$ and 56. The blood was collected in sterile Corvac ${ }^{13}$ integrated serum separator tubes (transport style, $15 \mathrm{ml}$ ) and was centrifuged at $2,000 \times g$. Serum samples were analyzed for cholesterol, triglycerides and lipoproteins using a Technicon SMAC system ${ }^{14}$ (sequential modular analysis with computer, model 397).

Fecal samples were collected at d 28, 35, 42,49 and 56 using the same procedure described for Exp. 1. Total lactobacilli were determined by plating a sample of the feces on acidified LBS agar; the number of fecal coliforms was determined on violet red bile $\operatorname{agar}^{8}$.

Statistical Analysis. Serum cholesterol, triglycerides, HDL and calculated LDL were analyzed by least-squares analyses of variance using the General Linear Models procedure as outlined by SAS (1982). Because initial sera values were different among pigs, they were used as covariates. Fecal counts were com-

\footnotetext{
${ }^{13}$ Sherwood Medical, St. Louis, MO.

${ }^{14}$ Roche Biomedical Laboratories, Wichita, KA.

${ }^{15} \mathrm{~A}$ procedure partially based on Bergey's manual of systematic bacteriology (Kandler and Weiss, 1986) keyed these same three strains to belong to one of two complexes: Lactobacillus acidophilus/gasseri complex or Lactobacillus acidophilus/amylovorus/crispatus/gasseri complex.
}

pared being multivariate analysis with a polynomial transformation.

\section{Results}

Experiment 1. Three out of 36 strains of Lactobacillus were determined to be of the species acidophilus. The key employed in the identification of species was based partially on Bergey's manual of determinative bacteriology (Rogosa, 1974) ${ }^{15}$. Glucose fermentation without carbon dioxide production indicates that a strain belongs to Group I, homofermentative, which can be further divided by ribose fermentation into either Thermobacterium IA (ribose negative) or Streptobacterium IB (ribose positive). The species acidophilus belongs to Group IA, homofermentative Thermobacterium. The results of the essential biochemical and physiological tests were:

TABLE 2. COMPOSITION OF HIGH-CHOLESTEROL DIETS FOR MATURE BOARS

\begin{tabular}{|c|c|c|c|}
\hline \multirow[b]{2}{*}{ Ingredient } & \multicolumn{3}{|c|}{ Diet } \\
\hline & $\begin{array}{l}\text { High } \\
\text { cholesterol }\end{array}$ & $(\mathrm{HC})$ & Yogurt $^{\mathbf{a}}$ \\
\hline & $-\%$ & compo & sition \\
\hline Ground corn & 62.70 & & 54.70 \\
\hline $\begin{array}{l}\text { Soybean meal } \\
(44 \% \text { protein) }\end{array}$ & 13.60 & & 18.70 \\
\hline Dried egg yolk ${ }^{b}$ & $10.60^{c}$ & & $13.30^{c}$ \\
\hline Beet pulp & 5.00 & & 5.00 \\
\hline Tallow & 3.00 & & 3.00 \\
\hline Dicalcium phosphate & 2.75 & & 2.75 \\
\hline Vitamin premix & 1.00 & & 1.00 \\
\hline Limestone & .60 & & .80 \\
\hline Iodized salt & .50 & & .50 \\
\hline DL-Methionine & .15 & & .15 \\
\hline Trace mineral premix ${ }^{\mathrm{e}}$ & .05 & & .05 \\
\hline Selenium premix $\mathrm{f}$ & .05 & & .05 \\
\hline
\end{tabular}

aFed in combination with $.454 \mathrm{~kg} /($ animal.d) acidophilus yogurt.

bHenningsen Foods Inc., David City, NE.

cProvided 2,914 and 3,644 $\mathrm{mg}$ of cholesterol/kg of $\mathrm{HC}$ and Yogurt diet, respectively.

dProvided the following per kg of complete diet: vitamin A, 5,512 USP; vitamin $\mathrm{D}_{3}$, $551 \mathrm{ICU}$; vitamin $\mathrm{E}, 22 \mathrm{IU}$; riboflavin, $5.5 \mathrm{mg}$; d-pantothenic acid, $19.8 \mathrm{mg}$; niacin, 33.1 $\mathrm{mg}$; choline chloride, $551.2 \mathrm{mg}$; vitamin $\mathrm{B}_{12}, .017 \mathrm{mg}$; vitamin $\mathrm{K}, 2.2 \mathrm{mg}$; ethoxyquin, $4.4 \mathrm{mg}$.

eProvided the following per kg of complete diet: Fe, 87.5 $\mathrm{mg}$; Zn, $75 \mathrm{mg}$; Mn, $30 \mathrm{mg}$; Cu, $8.75 \mathrm{mg} ; \mathrm{I}, 1 \mathrm{mg}$.

fProvided $.1 \mathrm{mg} \mathrm{Se} / \mathrm{kg}$ diet. 


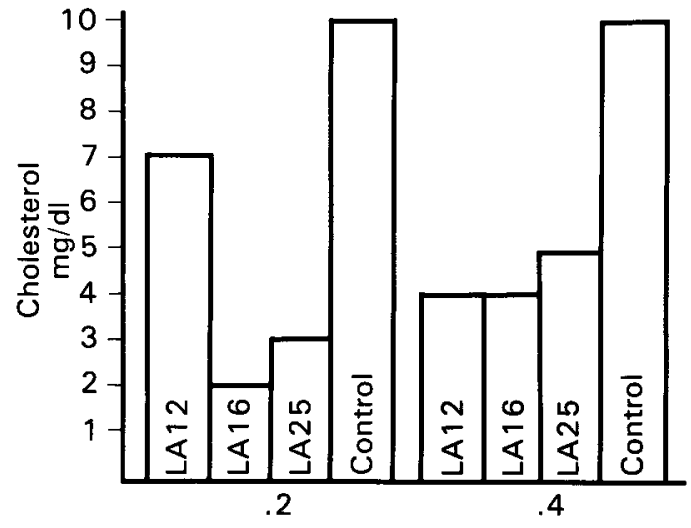

OX GALL (\%)

Figure 2. Residual cholesterol following $24 \mathrm{~h}$ in vitro incubation with porcine Lactobacillus acidophilus at two levels of ox gall (bile salts) $(\mathrm{SE}=0)$.

esculin hydrolysis $(+)$, mannitol $(-)$, melibiose $(-)$, lactose $(+)$, galactose $(t)$ and amygdalin $(+)$; additional non-essential confirmation tests results were: cellobiose $(+)$, maltose $(+)$, salicin $(+)$, sorbitol $(-)$, sucrose $(+)$, trehalose $(-), \mathrm{NH}_{3}$ from arginine $(-)$ and motility $(-)$. The three strains that fit this systematic design were then named LA12, LA16 and LA25. All three strains were considered to be highly bile tolerant because all produced heavy growth in MRS broth supplemented with either .2 or $.4 \%$ ox gall. In vitro cholesterol assimilation (Figure 2) indicated that strain LA16 lowered cholesterol by 80 and $60 \%$ at .2 and $.4 \%$ ox gall, respectively. Strain LA12 showed a $60 \%$ lowering of cholesterol at the $.4 \%$ level of ox gall but only $30 \%$ of the $.2 \%$ level. Strain LA25 lowered cholesterol by 70 and $50 \%$ at the two respective levels of ox gall. In vitro antimicrobial activity against both Bacillus subtilis and Escherchia coli (Figure 3) was the greatest for LA16, followed by LA12 and LA25.

LA12, LA16 and LA25 exhibited similar fermentation durations (curd formation starting 5 to $6 \mathrm{~h}$ and final pH attained by $8 \mathrm{~h}$ ), degree of whey production and quality of curd formation. Because LA16 showed bile tolerance, the greatest cholesterol reduction $(70 \%$ average), the greatest antimicrobial activity, and similar quality when made into yogurt, it was selected for yogurt production.

Experiment 2. During the 56-d test period, $16,18.9$-liter batches of yogurt were produced (one batch every $3.5 \mathrm{~d}$ ). This was done to ensure highly viable bacteria within the acidophilus yogurt. The 16 batches were consistent for $\mathrm{pH}$, plate count, gross energy, crude protein, calcium and phosphorus (Table 1). The plate count varied because the inoculation rate was changed from $2 \%$ to $4 \% \mathrm{LA}$ after the fifth batch of yogurt was produced. This change was implemented to increase the number of viable bacteria consumed by the boars.

The effect of yogurt on serum lipids is shown in Table 3 and Figure 4. Serum cholesterol was reduced by $10.5 \%$ in boars fed the yogurt diet $(P<.01)$. Serum triglycerides and HDL were not affected $(P>.23$ and $P>$ .11 , respectively), but serum LDL were reduced $(9 \%, P<.08)$ by feeding the yogurt diet. Because the LDL were calculated from serum cholesterol, triglycerides and HDL values, this response would be expected. The response of

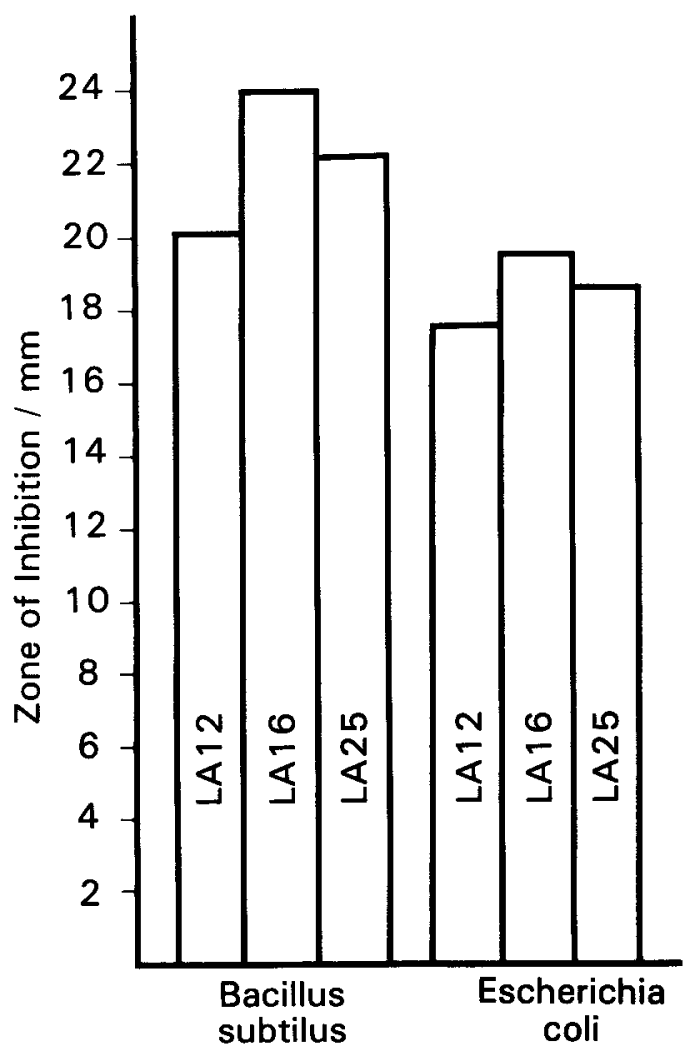

Figure 3. In vitro antimicrobial activity of porcine Lactobacillus acidophilus tested against Bacillus subtilis and Escherichia coli $(\mathrm{SE}=0)$. 
TABLE 3. EFFECT OF PORCINE ACIDOPHILUS YOGURT ON SERUM LIPIDS (d 56)

\begin{tabular}{|c|c|c|c|c|}
\hline \multirow[b]{2}{*}{ Liquid component } & \multicolumn{2}{|c|}{ Diet } & \multirow[b]{2}{*}{ Difference, $\%$} & \multirow[b]{2}{*}{ CV, \% } \\
\hline & $\begin{array}{l}\text { High } \\
\text { cholesterol }\end{array}$ & Yogurt & & \\
\hline $\begin{array}{l}\text { Cholesterol, mg/dlb } \\
\text { Triglycerides, mg/dlc } \\
\text { HDL, mg/dld } \\
\text { LDL, mg/dle }\end{array}$ & $\begin{array}{l}91.1 \\
52.2 \\
44.7 \\
33.7\end{array}$ & $\begin{array}{l}81.5 \\
48.8 \\
43.2 \\
30.8\end{array}$ & $\begin{array}{r}-10.5 \\
-6.5 \\
-3.4 \\
-8.6\end{array}$ & $\begin{array}{l}17.8 \\
33.3 \\
13.0 \\
29.6\end{array}$ \\
\hline
\end{tabular}

Least square means adjusted for initial sera values using covariate analysis.

bP $<.01$.

$c P>.23$.

${ }^{\mathrm{d}} \mathrm{HDL}=$ high density lipoproteins $(P>.11)$.

eLDL $=$ calculated low density lipoproteins $(P<.08)$; by Friedewalds' equation: $\mathrm{LDL}=$ serum cholesterol $-\mathrm{HDL}-$ (serum triglycerides/5).

serum cholesterol, triglycerides, HDL and LDL for the 56-d experiment is shown in Figure 4. Serum cholesterol and LDL exhibited the same patterns with the widening of the response traits for the two treatments occurring after d 14 and $\mathrm{d} 21$, respectively. No distinguishable patterns were demonstrated for serum triglycerides and $\mathrm{HDL}$.

The effect of dietary treatments on fecal lactobacilli and coliforms are shown in Figure

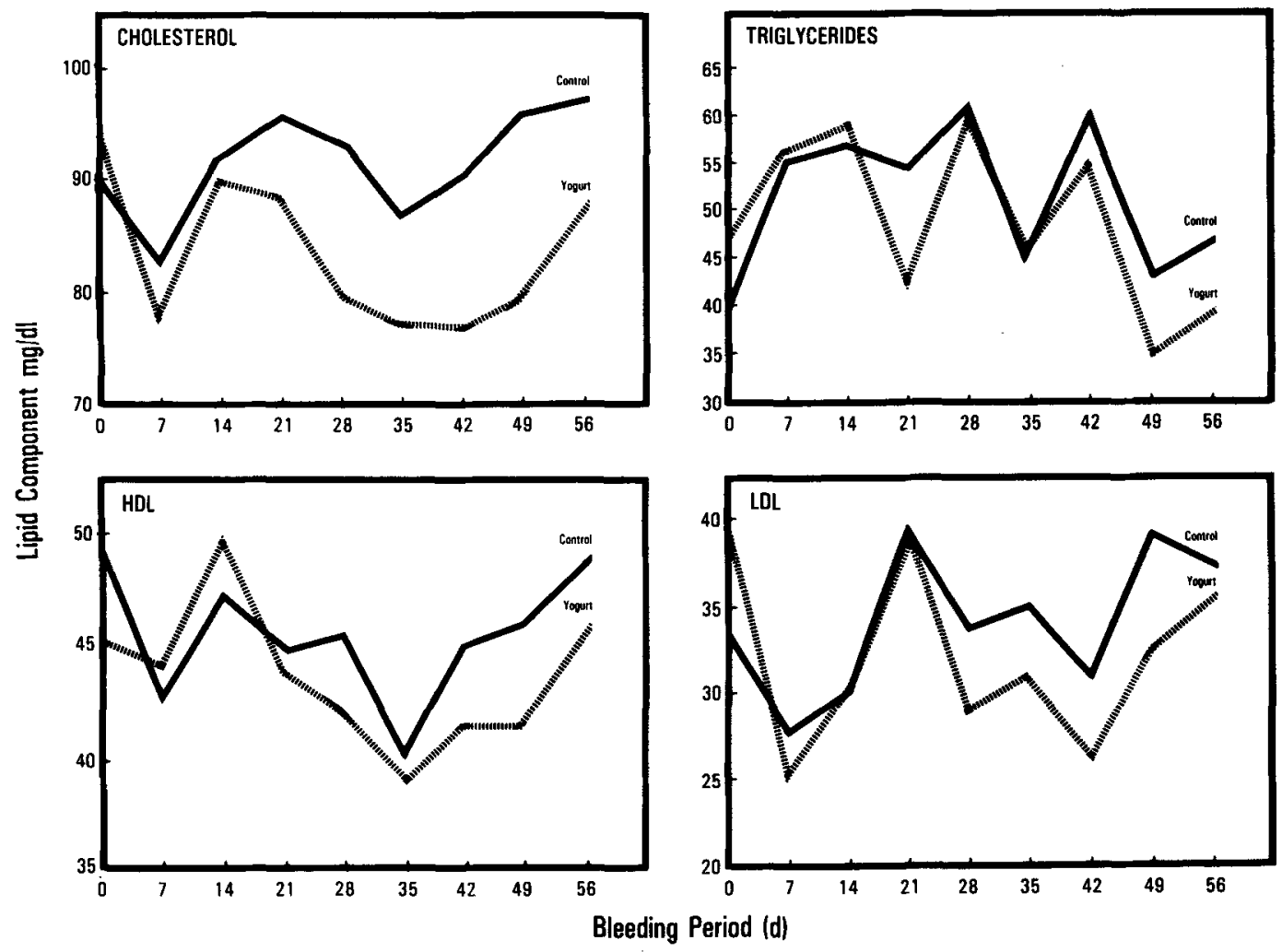

Figure 4. Effect of dietary acidophilus yogurt on serum cholesterol $(\mathrm{SE}=5.12)$, triglycerides $(\mathrm{SE}=5.61$ ), high density lipoproteins $(H D L)(S E=1.90)$ and low density lipoproteins $(L D L)(S E=3.19)$ of mature boars fed a high-cholesterol diet. Control diet $=$ solid line; yogurt diet $=$ dashed lines. 

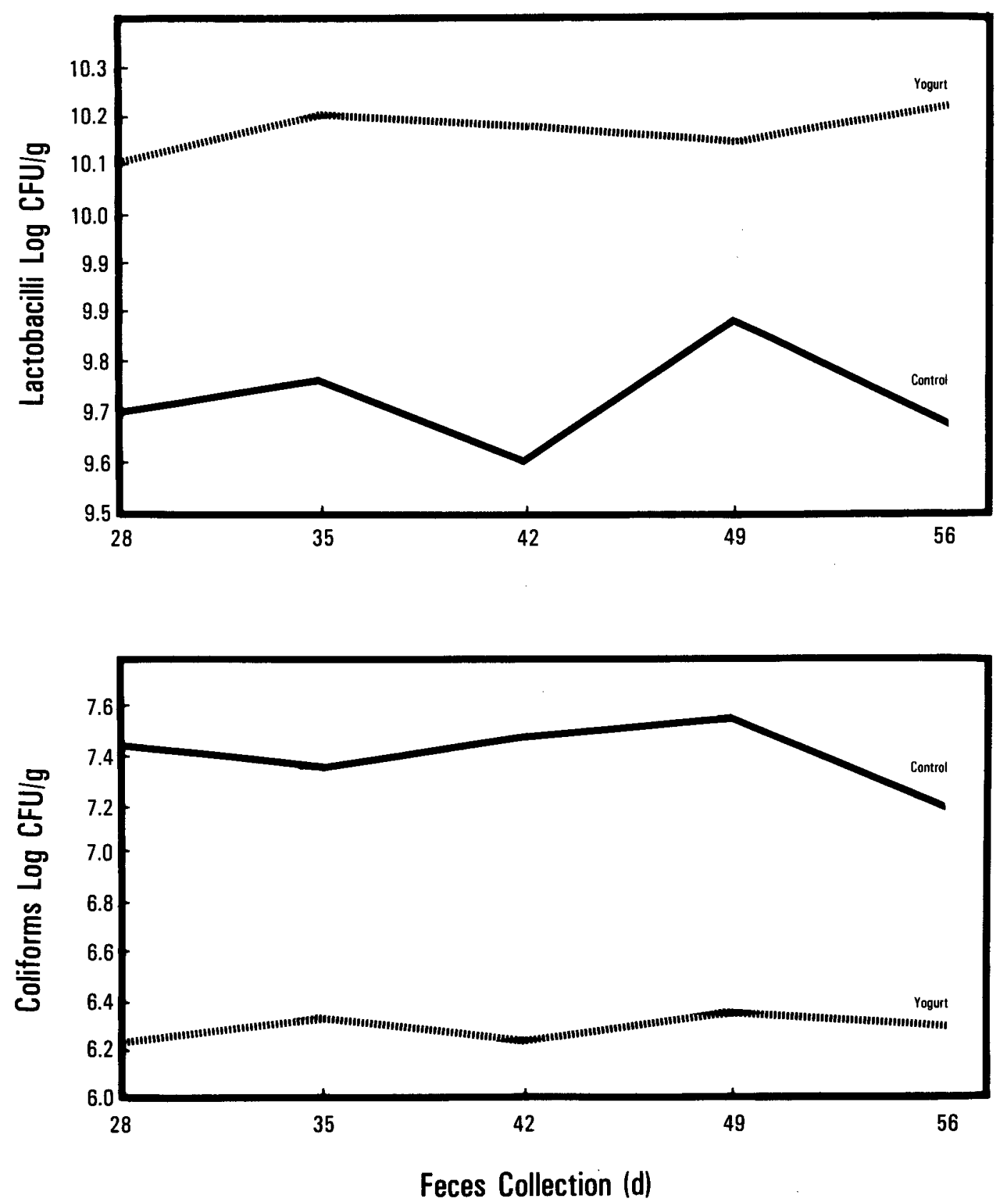

Figure 5. Effect of dietary acidophilus yogurt on fecal coliforms $(P<.0001$; pooled SE $=2.97)$ and lactobacilli $(P<.0001$; pooled $S E=4.92$ ) of mature boars fed a high-cholesterol diet. Control diet $=$ solid lines; yogurt diet $=$ dashed lines.

5 for d 28 to d 56. The $\log$ counts for lactobacilli and coliforms were $4 \%$ higher and $18 \%$ lower, respectively, for the boars fed yogurt than for the control animals over the 28-d span. There were significant time effects for both fecal coliforms $(P<.0010)$ and lactobacilli $(P<.0288)$. Even though there was a significant interaction between treatment and time for both fecal coliforms $(P<.0003)$ and lactobacilli $(P<.018)$, the authors believe that 
the significance demonstrated by the main effects is a real observation. The basis for this belief was that the polynomial transformation for time demonstrated a significant $(P<.0001)$ cubic effect for fecal coliforms and a quartic effect $(P<.0031)$ for fecal lactobacilli.

\section{Discussion}

The latest U.S. census (1986) describes the number-one cause of death in the U.S. as heart disease. When categorizing this disease by sex, males have a greater incidence of heart disease than females. Information published by the Lipids Research Clinics Program (1984) indicates that the higher the serum cholesterol level is in humans, the greater the chance for the development of coronary heart disease. Thus, increased research has sought ways to lower serum cholesterol levels in man.

Using physically mature boars as a model, serum cholesterol and LDL were reduced by feeding porcine Lactobacillus acidophilus yogurt in combination with a high-cholesterol diet. This finding agrees with research conducted with other species of animals: rabbits (Thakur and Jha, 1981), humans (Mann, 1977) and rats (Grunewald, 1982). The paradigm of the mechanism of this phenomenon is not universally agreed on. Gilliland et al. (1985) suggested that LA may be able to incorporate steroids into their cellular structure when grown under appropriate conditions. Nelson and Gilliland (1984) suggested that LA has the ability to act directly on cholesterol. Mann (1977) suggests that $\beta$ hydroxy- $\beta$-methyl glutaric acid (HGM) is the factor in yogurt that lowers serum cholesterol. Because HGM is present in such meager amounts in yogurt, Thakur and Jha (1981) concluded that some other factor such as $\mathrm{Ca}$ also might be responsible. Stahelin et al. (1981) found that casein and lactose are not responsible for this phenomenon; thus, something besides one of these bulk constituents of yogurt causes its cholesterol lowering effect.

Our data when applied to the correlation equations derived from the Framingham study (Truett et al., 1967) indicate that the risk of coronary heart disease would be reduced by $21 \%$ if adult males consumed AY in combination with high-cholesterol diets, assuming that the AY were made from strains of LA that assimilate cholesterol.

\section{Literature Cited}

Alm, L. and L. Pettersson. 1980. Survival rate of Lactobacilli during digestion. An in vitro study. Am. J. Clin. Nutr. 33:2543 (Abstr.).

AOAC. 1984. Official Methods of Analysis (14th Ed.). Association of Official Analytical Chemists, Washington, DC.

Chandan, R. C. 1982. Other fermented dairy products. In: G. Reed (Ed.) Prescott and Dunn's Industrial Microbiology. pp 113-184. AVI Publ. Co., Westport, CN.

Danielson, A. D. 1987. Effect of Lactobacillus acidophilus yogurt on cholesterol and lipid levels in mature boars. M. S. Thesis. Univ. of Nebraska, Lincoln.

Deeth, H. C. and A. Y. Tamime. 1981. Yogurt: nutritive and therapeutic aspects. J. Food Prot. 44:78.

Fiske, C. H. and Y. Subbarow. 1925. The colorimetric determination of phosphorus. J. Biol. Chem. 66:375.

Frobisher, M., R. D. Hinsdill, K. T. Crabtree and C. R. Goodheart. 1974. Fundamentals of Microbiology (9th Ed.). W. B. Saunders Co., Philadelphia, PA.

Gilliland, S. E., C. R. Nelson and C. Maxwell. 1985. Assimilation of cholesterol by Lactobacillus acidophilus. Appl. Environ. Microbiol. 49:377.

Grunewald, K. K. 1982. Serum cholesterol levels in rats fed skim milk fermented by Lactobacillus acidophilus. J. Food Sci. 47:2078.

Kandler, O. and N. Weiss. 1986. Genus Lactobacillus Beijerinck 1901,121. In: P.H. A. Sneath, N. S. Mair, M. E. Sharpe and J. G. Holt (Ed.) Bergey's Manual of Systematic Bacteriology. Vol. 2. pp 1209-1234. Williams and Wilkens Co., Baltimore, MD.

Leininger, H. V. 1976. Equipment, media, reagents, routine tests and stains. In: M. J. Speck (Ed.) Compendium of Methods for the Microbiological Examination of Foods. pp 79-80. American Public Health Association, Washington, DC.

Lipids Research Clinics Program. 1984. The Lipid Research Clinics coronary primary prevention trial results. 1. Reduction in incidence of coronary heart disease. $J$. Am. Med. Assoc. 251:351.

Mann, G. V. 1977. A factor in yogurt which lowers cholesteremia in man. Atherosclerosis 26:335.

Metchnikoff, E. 1907 . The prolongation of life. G. P. Putman's Sons, New York.

Miller, E. R. and D. E. Ullrey. 1987. The pig as a model for human nutrition. Ann. Rev. Nutr. 7:361.

Nelson, C. R. and S. E. Gilliland. 1984. Cholesterol uptake by Lactobacillus acidophilus. J. Dairy Sci. 67:50 (Abstr.).

Pelkonen, R., E. A. Nikkila, S. Koskinen, K. Penttinen and S. Sarna. 1977. Association of serum lipids and obesity with cardiovascular mortality. Br. Med. J. 2:1185.

Pond, W. G., H. J. Mersmann and J. T. Yen. 1986. Blood plasma cholesterol and response of the cardiovascular system to diet in obese and lean swine. Swine Res. Rep. No. 2. pp 47-49. R.L.H. USMARC, Clay Center, NE.

Rogosa, M. 1974. Genus Lactobacillus Beijerinck 1901,212. In: R. E. Buchanan and N. E. Gibbons (Ed.) Bergey's Manual of Determinative Bacteriology. pp 576-593. Williams and Wilkens Co., Baltimore, MD.

SAS. 1982. SAS User's Guide. SAS Inst., Inc., Cary, NC. Shahani, K. M. and R. C. Chandan. 1979. Nutritional and healthful aspects of cultured and culture-containing dairy foods. J. Dairy Sci. 62:1685.

Shahani, K. M., J. R. Vakil and A. Kilara. 1976. Natural antibiotic activity of Lactobacillus acidophilus and 
bulgaricus. I. Cultured condition for the production of antibiosis. Cult. Dairy Prod. J. 11:14.

Stahelin, H. B., G. Ritzel, M. Wanner, M. Jost and H Schneeberger. 1981. Hypocholesterolemic effect of milk constituents in growing swine. Int. J. Vit. Nutr. Res. 51(2):198.

Thakur, C. P. and A. N. Jha. 1981. Influence of milk, yogurt and calcium on cholesterol-induced atherosclerosis in rabbits. Atherosclerosis 39:211.

Truett, J., J. Cornfield and W. Kannel. 1967. A multivariate analysis of the risk of coronary heart disease in Framingham. J. Chronic Dis. 20:511.

U.S. Bureau of the Census. 1986. Statistical Abstract of the United States: 1987. 107th Ed. Washington, DC. 